\section{Squamous cell carcinoma of the stomach}

\section{Introduction}

Pure primary squamous cell carcinoma (SCC) of the stomach is extraordinarily rare. To date fewer than 100 cases have been found in world literature. We describe here a case of locally advanced SCC of the stomach in a 67-year-old man with severe anemia, and the present case met all the criteria for diagnosing this uncommon gastric malignancy. Surgery offers an effective treatment option for patients suffering from this rare subtype of gastric cancer.

\section{Case report}

A 67-year-old man was admitted to the University Hospital of the State University of Campinas, Brazil, with complaints of asthenia since last two months. His past medical history included hypertension being treated with nifedipine, a previous episode of stroke, and depression, which was being treated with sertraline. He denied tobacco or alcohol use. On physical examination, he was moderately pale and slightly lethargic, without any other abnormalities. Laboratory tests revealed: haemoglobin $4.1 \mathrm{~g} / \mathrm{dL}$, red blood cell count $2.13 \times 10^{12} / \mathrm{L}$, haematocrit $14.8 \%$, mean cell volume $69.5 \mathrm{fL}$, mean cell haemoglobin $19.2 \mathrm{pg}$, and red cell distribution width $20.1 \%$.

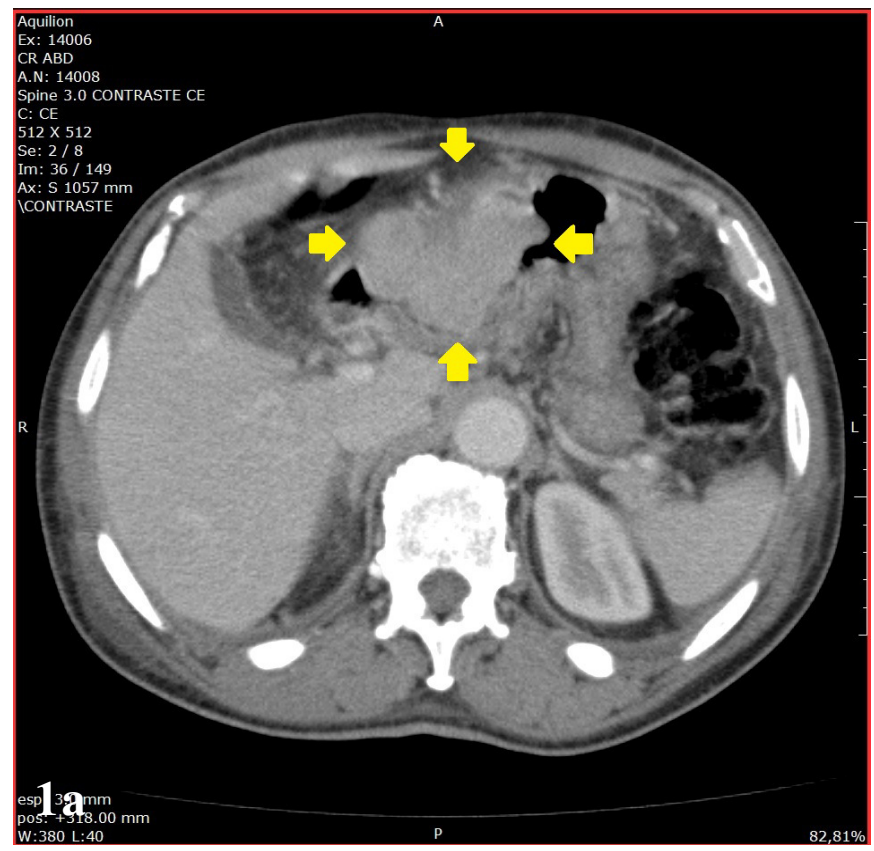

Biochemical parameters including renal and liver tests were normal. Upper gastrointestinal endoscopy identified an advanced, obstructive, haemorrhagic gastric neoplasm, classified as Borrmann I, whose histopathology revealed a poorly to moderately differentiated squamous cell carcinoma (SCC). Abdominal computed tomography (CT) showed thickening of the gastric wall, especially in the antrum, with extension to the body, suggestive of a neoplastic pathology. There was also densification of perigastric adipose tissue; lymph nodes measuring $2.8 \times 0.6 \mathrm{~cm}$ adjacent to the lesser curvature, and a lymph node measuring $1.0 \times 1.5 \mathrm{~cm}$, adjacent to the gastric antrum (Figure 1). CT scan of the thorax revealed no evidence of metastasis or other primary tumor.

One week after admission, a radical subtotal gastrectomy with Roux-en-Y reconstruction and D2 lymphadenectomy was performed. The postoperative period was uneventful. The resected specimen showed a polypoid tumor (Borrmann I) in the distal stomach, measuring $8.0 \times 5.5 \times 4.5 \mathrm{~cm}$. An extensive histological investigation using hematoxylin and eosin stained sections was performed (at least 2 sections per centimeter of tumor mass). Histolopathology revealed a SCC without an adenocarcinoma component. The degree of differentiation varied from moderately differentiated with keratin pearl formation (Figure 2) in most of the tumor to staggered areas of poorly differentiated cells. The carcinoma had infiltrated full thickness of the gastric wall without perforating through the serosa and three out of forty two perigastric lymph nodes were positive for metastatic SCC. The final diagnosis was a locally

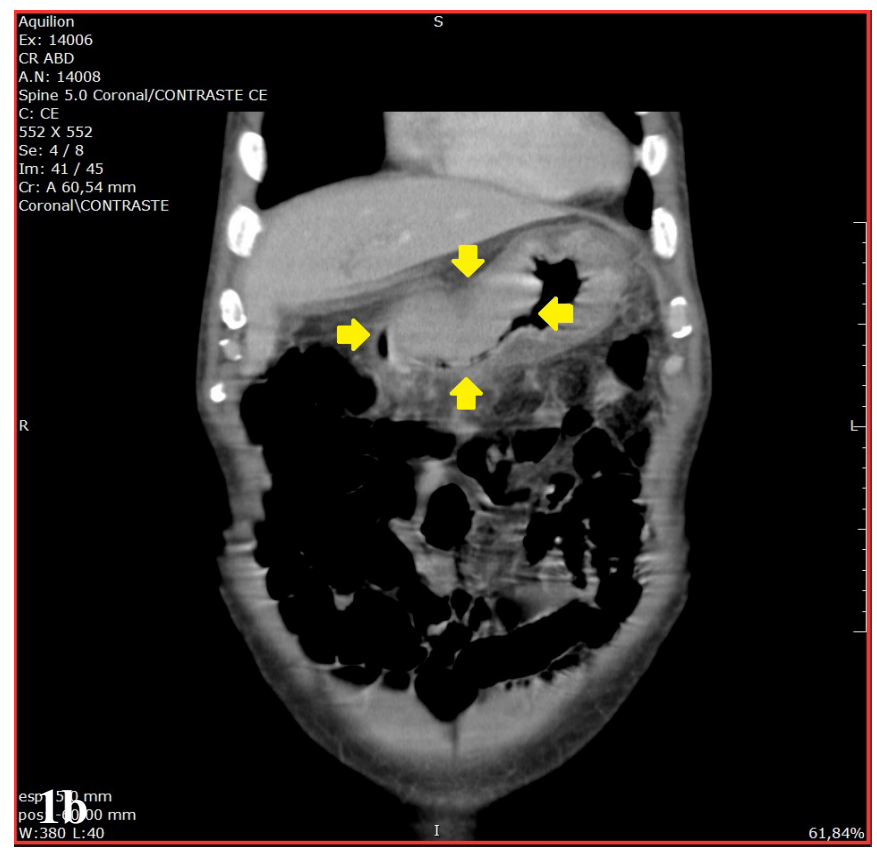

Figure 1: Abdominal CT scan showing thickening of the gastric wall in the antrum and body 

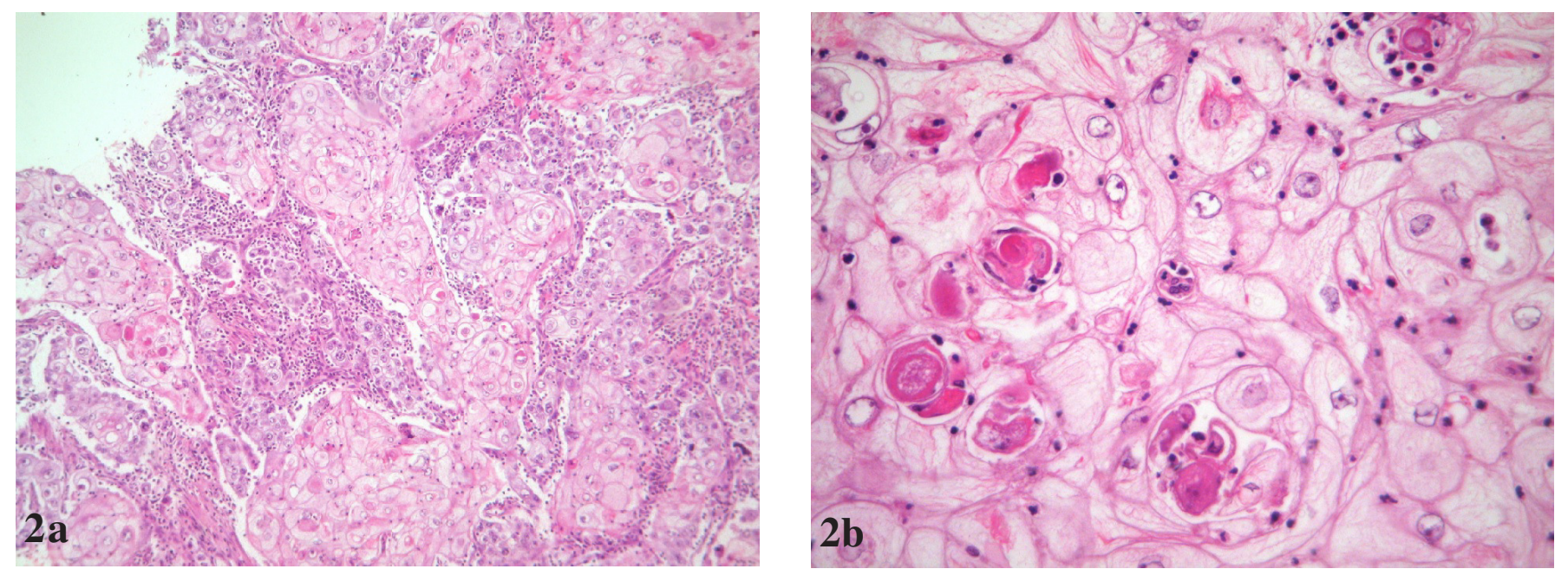

Figure 2: SCC with keratin pearl formation without any adenocarcinomatous component (hematoxylin and eosin, 100x and 250x)
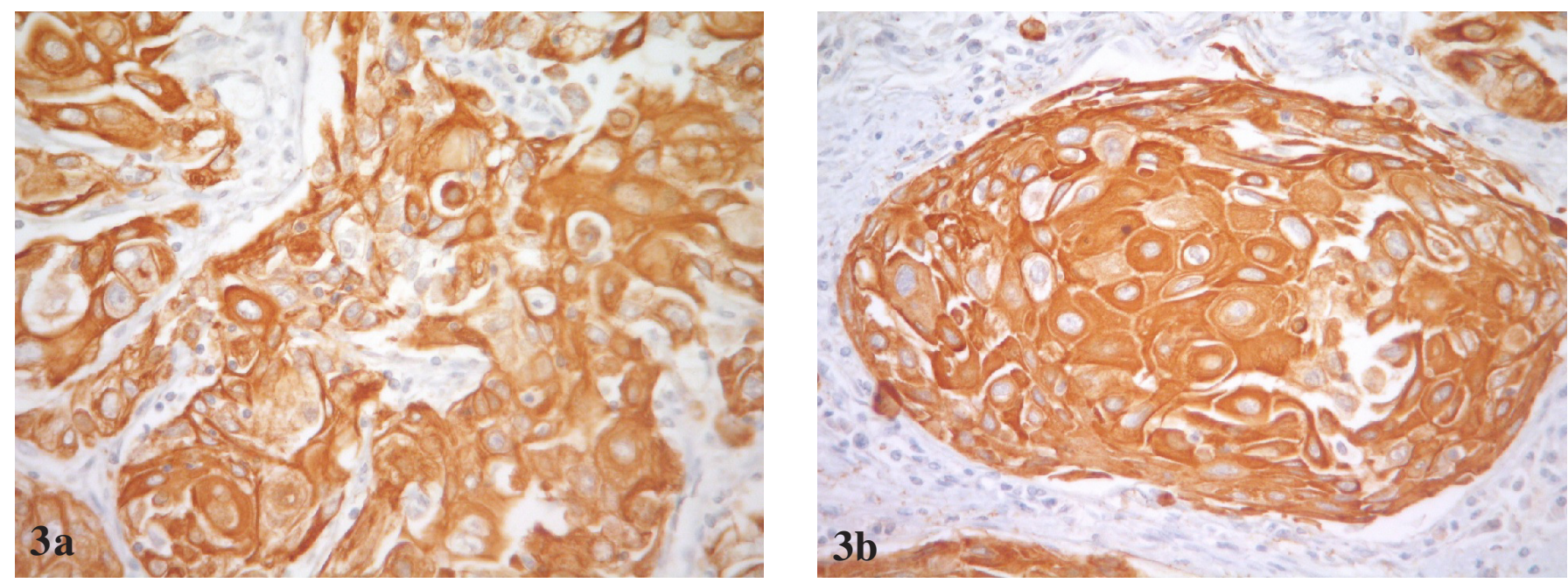

Figure 3: Immunohistochemistry (200x) showing diffuse cytoplasmic expression for CK5/6 in neoplastic cells

advanced primary SCC of the distal stomach. The pathologic stage was IIIA (pT3 pN2 cM0), based on the AJCC Manual, $7^{\text {th }}$ edition. Immunohistochemistry showed neoplastic cells positive for cytokeratins (AE1/AE3, CK7 and CK5/6) and p63, confirming the diagnosis of SCC (Figure 3). Even though adjuvant therapy has led to improved outcomes in adenocarcinoma of the stomach, and SCC of the stomach seems to be more aggressive, the patient chose not to receive adjuvant chemoradiotherapy, but remained on follow-up with regular imaging. In his last visit, thirty six months after the procedure, the patient was free of recurrence and without any complaint.

\section{Discussion}

Gastric cancer is the fourth most common type of malignancy and the second most common cause of death from cancer worldwide, with approximately 989,600 new cases and 738,000 deaths per year. ${ }^{1,2}$ Adenocarcinoma is the most frequent histologic type, accounting for more than $90 \%$ of gastric cancers. On the other hand, pure primary SCC of the stomach is an exceedingly rare lesion. It was first described in $1895 .^{3}$ Since then, fewer than 100 cases have been reported, many of them from Japan. ${ }^{4}$ The incidence ranges from $0.04 \%$ to $0.7 \%$ of all gastric cancers. ${ }^{5}$ It occurs mostly in men (male-to-female ratio of 5:1), and shows a peak incidence in the sixth decade of life. ${ }^{4,6}$ Most of the cases are diagnosed at an advanced stage with a mean survival of a few months. ${ }^{7}$ The following factors have already been related to SCC of the stomach in solitary cases, mostly associated with foci of squamous metaplastic epithelium: corrosive acid burns, ${ }^{8}$ luetic linitis plastica, ${ }^{9}$ longterm treatment with cyclophosphamide,${ }^{10}$ dermatomyositis, ${ }^{11}$ following chemotherapy for generalized well-differentiated lymphocytic lymphoma, ${ }^{2}$ gastric stump, ${ }^{13}$ and Ménétrier's disease. ${ }^{5}$ The pathogenesis remains obscure and controversial. Several mechanisms have been postulated: ${ }^{14}(1)$ nests of ectopic squamous epithelium in gastric mucosa; (2) squamous 
metaplasia of the gastric mucosa before malignant transformation; (3) multipotent stem cells in gastric mucosa; and (4) squamous differentiation of a preexisting adenocarcinoma. However, in majority of the reported cases none of these factors were demonstrated.

These tumors may present with lymphovascular invasion, ${ }^{15}$ and the commonest metastasis has been observed to the liver and peritoneal surface. ${ }^{16}$ Generally, it is considered as more aggressive than adenocarcinoma. ${ }^{15,17,18}$ Grossly and radiologically the tumor is indistinguishable from adenocarcinoma and may involve any portion of the stomach, especially along the lesser curvature. ${ }^{19}$ The three anatomic diagnostic criteria for primary SCC of the stomach are as follows: ${ }^{20}$ (1) the tumor must not be located in the cardia; (2) the tumor must not extend into the oesophagus and (3) there must be no evidence of SCC in any other organ. Furthermore, there are four histopathological criteria that need to be taken into consideration in the diagnosis of SCC of the stomach: ${ }^{21}$ (1) keratinized cell masses forming keratin pearls; (2) a mosaic cell arrangement; (3) intracellular bridges and (4) high concentrations of sulphydryl or disulphide bonds. This case satisfied all the diagnostic criteria laid down in literature.

\section{RODRIGO DE ASSIS MORAES ${ }^{1}$ \\ LUCIANA RODRIGUES DE MEIRELLES ${ }^{2}$ \\ NELSON ADAMI ANDREOLLO ${ }^{3}$ JOSÉ BARRETO CAMPELLO CARVALHEIRA ${ }^{1}$}

Correspondence: Dr. Rodrigo de Assis Moraes Department of Internal Medicine, Clinical Oncology Division, ${ }^{1}$ Department of Pathology, ${ }^{2}$

Department of Surgery, Digestive Disease Division, ${ }^{3}$ School of Medicine, State University of Campinas (UNICAMP),

Brazil

Email: ramoraes@fcm.unicamp.br

\section{References}

1. Jemal A, Bray F, Center MM, Ferlay J, Ward E, Forman D. Global cancer statistics. CA Cancer J Clin. 2011;61:69-90.

2. World cancer report. IARC website; [accessed 2012 Sept 16]. Available from: www.iarc.fr/en/publications/pdfs-online/wcr/.

3. Rörig R. Primares cancinoid des magens. [Thesis]. Wurzburg: P. Scheiner, 1895.

4. Callacondo D, Ganoza-Salas A, Anicama-Lima W, QuispeMauricio A, Longacre TA. Primary squamous cell carcinoma of the stomach with paraneoplastic leukocytosis: a case report and review of literature. Hum Pathol. 2009;40:1494-8.
5. Choi SB, Park SS, Oh SY, Kim JH, Kim WB, Lee JH, et al. Primary squamous cell carcinoma of the stomach that developed with Menetrier's disease. Dig Dis Sci. 2007;52:1722-4.

6. Schmidt C, Schmid A, Luttges JE, Kremer B, Henne-Bruns D. Primary squamous cell carcinoma of the stomach. Report of a case and review of literature. Hepatogastroenterology. 2001;48:1033-6.

7. Tokuhara K, Nakano T, Inoue K, Nakane Y, Kwon AH. Primary squamous cell carcinoma in the gastric remnant. Surg Today. 2012;42:666-9.

8. Eaton H, Tennekoon GE. Squamous carcinoma of the stomach following corrosive acid burns. Br J Surg. 1972;59:382-7.

9. Vaughan WP, Straus FH 2nd, Paloyan D. Squamous carcinoma of the stomach after luetic linitis plastica. Gastroenterology. 1977;72:945-8.

10. McLoughlin GA, Cave-Bigley DJ, Tagore V, Kirkham N. Cyclophosphamide and pure squamous-cell carcinoma of the stomach. Br Med J. 1980;280:524-5.

11. Hisamura M, Minami Y, Ide H, Kaji H, Murao M, Kikuchi Y. [A case report of a primary pure squamous cell carcinoma of the stomach associated with dermatomyositis (author's transl)]. Hokkaido Igaku Zasshi. 1981;56:89-93.

12. Callery CD, Sanders MM, Pratt S, Turnbull AD. Squamous cell carcinoma of the stomach: a study of four patients with comments on histogenesis. J Surg Oncol. 1985;29:166-72.

13. Ruck P, Wehrmann M, Campbell M, Horny HP, Breucha G, Kaiserling E. Squamous cell carcinoma of the gastric stump. A case report and review of the literature. Am J Surg Pathol. 1989;13:317-24.

14. Straus R, Heschel S, Fortmann DJ. Primary adenosquamous carcinoma of the stomach. A case report and review. Cancer. 1969;24:985-95.

15. Volpe CM, Hameer HR, Masetti P, Pell M, Shaposhnikov YD, Doerr RJ. Squamous cell carcinoma of the stomach. Am Surg. 1995;61:1076-8.

16. Akbulut S, Finci R, Ozyilkan E. Primary squamous cell carcinoma of the stomach: a case report. Acta Gastroenterol Belg. 2003;66:189-90.

17. Mori M, Iwashita A, Enjoji M. Adenosquamous carcinoma of the stomach. A clinicopathologic analysis of 28 cases. Cancer. 1986;57:333-9.

18. Kim YS, Heo WS, Chae KH, Gang YS, Jung JH, Kim SH, et al. [Clinicopathological features and differences of p53 and Ki-67 expression in adenosquamous and squamous cell carcinomas of the stomach]. Korean J Gastroenterol. 2006;47:425-31.

19. Won OH, Farman J, Krishnan MN, Iyer SK, Vuletin JC. Squamous cell carcinoma of the stomach. Am J Gastroenterol. 1978;69:594-8.

20. Parks RE. Squamous neoplasms of the stomach. Am J Roentgenol Radium Ther Nucl Med. 1967;101:447-9.

21. Boswell JT, Helwig EB. Squamous Cell Carcinoma and Adenoacanthoma of the Stomach. A Clinicopathologic Study. Cancer. 1965;18:181-92. 